\title{
Rare neurological diseases in children: current paradigm of communicational interventions and inclusion
}

\section{Рідкісні неврологічні захворювання у дітей: сучасна парадигма комунікаційних втручань та інклюзії}

Armenuhi Avagyan

Ph.D. in Special Pedagogy, Associate Professor

\section{Арменуш Авагян}

кандидат наук у галузі спеціальної педагогіки, доцент

E-mail: avagyan.aspu@gmail.com

ResearchID: S-5979-2018

Hasmik Mkrtchyan

Ph.D. student
Хасмік Мкртчян

аспірант

E-mail: hasmikmh@mail.ru

ResearchID: S-5974-2018

Tigran Petrosyan

Ph.D. in Biological Sciences,

Associate Professor
Тигран Петросян

кандидат біологічних наук, доцент

\section{E-mail: petrosyantigran56@aspu.am orcid.org/0000-0002-5517-8856 \\ ResearchID: S-5966-2018}

Armenian State Pedagogical University after Kh. Abovyan,

Department of Speech and

Rehabilitation Therapy

$\triangle 17$, Tigran Mets Avenue,

Yerevan, Armenia
Вірменський державний педагогічний університет імені Х. Абовяна, кафедра логопедіі та відновлюваної терапї $\bowtie$ просп. Тиграна Меца, 17, Єреван, Вірменія

Original manuscript received August 14, 2018

Revised manuscript accepted October 10, 2018 


\section{ABSTRACT}

The goal of the presented work is to identify the optimum strategy for the enhancement of communication in patients with rare neurological disorders based on different models. With rapidly developing alternative communication technologies it becomes essential to identify an access method for a child and chose the alternative system of communication. Communication difficulties are common in children with rare neurological disorders. These disorders are manifested with motor, cognitive and sensory deficit. Speech and language therapy applied in these categories of patients is presented in various research publications. When forming a message, human communicators typically use a combination of modes: cognitive, psychological, or psycholinguistic sense to facilitate the way children construct internal representations that can be encoded and presented in different forms. Comprehensive assessment and recommendation of appropriate augmentative and alternative communication $(A A C)$ systems are critical factors in the success of interventions for individuals with rare neurological disorders who have complex communication needs. The assessment of communication difficulties associated with rare diseases is an essential factor for the development of AAC technologies for these pediatric patients. The methods applied in the presented research are: analysis of different studies and, systematization and generalization of the research evidence. Enhancement of communication in patients with rare neurological disorders should be based on the integration of cognitive, psychological, or psycholinguistic models. For children with rare neurological disorders that eventually lead to speech, cognitive and psychological disturbances, AAC methods are the strategies of choice to facilitate communication. These tools with different access methods are used to support inclusion of children with rare neurological conditions into education system.

Key words: alternative communication systems, inclusive education, rare neurological disorders.

\section{Introduction}

Communication difficulties are common in children with rare neurological disorders. These disorders are manifested with motor, cognitive and sensory deficit. Speech and language therapy applied in these categories of patients is presented in various trials and research publications. Comprehensive assessment and recommendation of appropriate augmentative and alternative communication (AAC) systems are critical factors in the success of interventions for individuals with rare neurological disorders who have complex communication needs. 
Prader-Willi syndrome (PWS) is a rare chromosomal disorder caused by the absent expression of paternally inherited genes in the PWS critical region on chromosome 15. In approximately $55-60 \%$ of affected individuals there is a microdeletion of the long arm of paternal chromosome 15 (15q11-q13), whereas up to the $45 \%$ of subjects have a maternal uniparental disomy for the same chromosome (UPD15) (Lionti et al., 2015). Abnormalities of the imprinting center controlling the activity of imprinted genes or translocations involving chromosome 15 have been found in few cases. PWS represents the single most common known genetic cause of obesity, with a population prevalence of no less than 152,00. A complex hypothalamic-pituitary dysregulation is currently thought to be partly responsible for the PWS phenotype. The syndrome affects multiple organ systems and its most consistent characteristics include muscular hypotonia, characteristic appearance, neuropsychomotor developmental delay, behavioral and psychiatric disturbances, hypogonadism, restricted longitudinal growth, growth hormone $(\mathrm{GH})$ insufficiency, and hyperphagia. Prevalence figures for PraderWilli are estimated at 1 in 1000, with the majority having speech, language or communication needs. Prevalence of the need for AAC in the UK Using expert input, it was determined that 4-6 people per 1000 have PraderWilli with speech, language or communication needs and could benefit from AAC.

Williams syndrome (WS), also referred to as Williams Beuren syndrome, is a rare genetic disorder which results in specific physical, medical, behavioral and cognitive outcomes. Physical features of WS can include small stature, dysmorphic facial features, a hoarse voice, hyperacusis and transient-neonatal hypercalcaemia. Medically, there can be connective tissue abnormalities, decreased motor coordination and balance, as well as reduced muscle tone and a high frequency of cardiovascular abnormalities, typically supravalvular aortic stenosis and peripheral pulmonary stenosis (Antonell et al., 2010). Individuals with WS can experience generalized anxieties, fears and specific phobias, and have difficulties with attention and can be distractible and hyperactive. Infants and young children with WS typically present with developmental delay. Intellectual and learning disabilities are also reported in most individuals with WS, with overall functioning typically at the level of a mild to moderate impairment, although the intellectual disability level has been found to range widely from severe intellectual 
disability to the average to low average range. Likewise literacy skills range widely from an inability to read to average for age. Moreover, there have been reports of specific strengths and weaknesses in the cognitive profile of WS, characterized by relative strengths in certain verbal abilities including receptive vocabulary; grammatical abilities; verbal short-term memory; and (concrete) nonverbal reasoning, but with considerable weaknesses in visuospatial constructional abilities; relation/ conceptual language (spatial, dimensional and temporal concepts) and pragmatics (Mervis, 2010).

The number of people with Williams syndrome is approximately 13 in 1000. Using expert input, it was determined that 2 people per 1000 have Williams syndrome with speech, language or communication needs and could benefit from AAC.

Locked-in syndrome (LIS) or pseudocoma, is a pathology in which a patient is conscious but is not able to move and communicate verbally because of complete paralysis of almost all voluntary body muscles in except for eye movements. Total locked-in syndrome is a type of locked-in syndrome when the eyes are also paralyzed.

The figures for locked-in syndrome are not well established and the estimate here is based on adapting numbers from the Association of Locked-in Syndrome. Between 1997 and 2004 there were 367 people registered in France with locked-in syndrome although these figures were generally considered to be an underestimate of the total number (Laureys et al., 2005). These figures suggest a prevalence of 2 per 1000 . The nature of the condition means that all of the cohort will have communication needs. Using expert input, it was determined that 0.3 people per 1000 have locked-in syndrome with speech, language or communication needs and could benefit from AAC.

Rett syndrome (RTT) is an X-linked progressive neurodevelopmental disorder that affects females. Mutations in the X-linked methyl-CpG-binding protein 2 gene (MECP2; MIM 300005) are the major cause of RTT. The phenotypic spectrum of RTT is highly variable. The most recent classification has identified typical and variant forms of RTT. MECP2 mutations has been attributed to be the single largest genetic cause of RTT phenotypes with recent data suggesting over $95 \%$ of classical RTT cases and over $75 \%$ of variant RTT cases resulted from mutations in this gene (Neul et al., 2014). The clinical features of classical RTT are characterized by a period of apparently normal 
development, quickly superseded by a period of severe developmental regression leading to diminished intellectual, motor, communication, and hand movement skills. In the classical variant, clinical clues become apparent at 6-18 months, with progressive failure thereafter. In human females, the phenomenon of X-chromosome inactivation, where there is transcriptional silencing of one of the alleles of genes on the $\mathrm{X}$-chromosome, can influence disease severity in X-linked disorders.

Some cases of males with mutations in MECP2 and a RTT or RTT-like phenotype surviving beyond infancy have been noted (Reichow et al., 2015). In addition, some males may exhibit a classical RTT phenotype because of X-chromosome aneuploidy or somatic mosaicism or may have a milder phenotype in the context of specific mutations.

Approximately 0.4 people per 1000 have Rett syndrome, almost exclusively affecting females. All the people affected by this condition will have severe communication impairments and, in addition to severe dysarthria, there may be difficulties with initiation of communication by the individuals. Using expert input, it was determined that 0.2 people per 1000 have Rett syndrome with speech, language or communication needs and could benefit from AAC.

Angelman syndrome-is a rare genetic disorder which affects the nervous system. Typical features of this disease include delayed development, intellectual disability, expressed speech impairment, and problems with movement and balance (ataxia). Majority of children have recurrent seizures (epilepsy) and microcephaly. Delay in development becomes apparent by the age of 6-12 months, but other signs usually become apparent in early childhood.

Children with-Angelman syndrome-usually are characterized with a happy, excitable demeanor and frequent smiling, laughter, handflapping movements, as well as hyperactivity. Most patients also have difficulty sleeping. With age, people with-this syndrome-become less excitable, and the sleeping problems become less expressed.

The prevalence figures for this rare syndrome are estimated from Danish figures (Schnewolf-Greulich et al., 2017) at 1per 1000 population. Using expert input, it was determined that 0.2 people per 1000 have Angelmans syndrome with speech, language or communication needs and could benefit from AAC.

The goal of the presented work is to identify the optimum strategy for the enhancement of communication in patients with rare neurological 
disorders based on cognitive, psychological, or psycholinguistic models. With rapidly developing alternative communication technologies it becomes essential to identify an access method for a child to choose the alternative system of communication.

\section{Methods and techniques of the research}

The methods applied in the presented research were: analysis of different studies and trials, systematization and generalization of the research evidence.

\section{Criteria for the selection of studies}

There were a number of criteria specified for the selection of studies for this review: (a) The studies were published between 2006 and 2017, (b) they involved individuals with developmental disabilities who had significant speech impairments, (c) they included usage of AAC and (d) they presented data on speech production for the patients before and after AAC intervention require AAC (American SpeechLanguage-Hearing Association, 1991). Studies of individuals who had acquired disabilities were excluded.

\section{Search procedure}

A multifaceted search strategy was applied to find all studies that met the selection criteria and to avoid a biased yield. First, electronic searches of various databases (i.e., PsycINFO, ERIC, Medline) were conducted using keywords (i.e., 'alternative communication systems', 'rare neurological disorders', 'augmentative communication', 'inclusive education').

The second step in the search was to review the contents of selected 13 articles. Four of the 13 journals (31\%) were randomly picked and searched by one of our graduate students to determine the reliability of the search rocedures. A total of 289 articles were reviewed using the selection criteria described above. The interater reliability was nearly $100 \%$ for the search procedures (i.e., 289 agreements out of 289 total articles). Any discrepancy arisen was discussed and subsequently resolved.

\section{Analysis of the best evidence}

In this research review we used the best evidence analysis (Slavin, 1986) which is based on the basis of the certainty of evidence provided 
by the authors. The best evidence approach integrates the analysis of quantitative outcome measures with an evaluation of the quality of the study and the certainty of the evidence that the studies present. Greater advantage is given to the studies with best evidence available that use more rigorous designs.

\section{Results and Discussion}

\section{Alternative and augmentative communication systems for pediatric patients with rare neurological diseases}

Speech generating is a complex process involving a number of processes and modes to use. When forming a message, human communicators typically use a combination of modes: cognitive, psychological, or psycholinguistic sense to facilitate the way children construct internal representations that can be encoded and presented in different forms. Pediatric patients with rare neurological diseases that have communication problems may make use of equipment, technologies and approaches, that are determined as augmentative and alternative communication (AAC), to enhance the expressive and receptive communication. According to the American Speech Language and Hearing Association AAC is a large group of procedures that help to increase the patient's communication skills. Clinical trials have shown that communication disorder can be associated to more complex restrictions in child activities. The main purpose when selecting an AAC system is to increase the patient's participation in a wide range of life situations, and giving the child a chance to pass information, make choices and control the environment around them. AAC systems are usually divided into three types: so called no-tech systems (e.g. manual signaling systems, gestures), low-tech systems that include printed materials (e.g. communication books, boards) and high-tech systems (e.g. complex voice output systems, computers or tablet devices adjusted for patients, recording devices) (Borgestig et al., 2015). For pediatric patients, whose communication difficulties are one of the manifestations of their physical disability caused by any rare neurological disease, the use of manual signs may be not so efficient with gross and fine motor control. For such patients, the use of high-tech technology is often considered as an option of supporting the communication, particularly the expressive language. However, if the technologies are used accurately it may be necessary to identify an alternative way for a 
child to chose other high-tech systems. This is the usual way to identify an access method.

The basic principles of patient assessment that are used for the selection of an appropriate access method are based on the International Classification of Functioning, Disability and Health (ICF) which is a widely used decision-making framework (Carnahan et al., 2007).

Composing a message using a high-tech AAC device needs a proper selection of one or more items included in the database of words (pictures, etc) to compose a message and then transmit the information. Development of these systems is based on application of advanced technologies such as ipad, tablet computers, notebooks or desktops. Such systems will help individuals with communication, as well as with a wide range of functions such as recording, social media and web content assessment, environmental control processes that facilitate independent living.

It is well known that an optimal seated position is able to support trunk control and functions of upper limb, including application of utilities for accessing AAC. However, an essential aspect should be pointed to, regarding the use of special systems, emphasizing the importance of alternative access points, such as the eyes for the eyegaze access technology. This aspect has not yet been well studied in the research field. Nonetheless, knowledge required for the development of movement patterns and skills of executive functioning would indicate that if multiple repeated movements are promoted through adequate positioning of the child and the peripherals needed to control the device, they will experience an increase in the efficient control over performance, resulting in the elaboration of automaticity.

Decreasing the cognitive load which is associated with physical access may facilitate the child's ability to focus not only on the navigational, but also psycholinguistic complexities related to application of an AAC device (Higginbotham et al., 2007).

After gaining a complete understanding of patient's motor abilities, regardless of the neurological diagnosis, a multidisciplinary clinical team can then initiate the process of selecting equipment to enhance the independent movements and translate them into control of an AAC system. All access methods are described as having a group of common, inter-related parameters and components: an input device, a method for selection, a list of items from which to select a feedback method. Trying 
to select a reliable and efficient access method, all components must be considered, with adaptations made to each according to the specific needs of the patient controlling the AAC device, and the type of the motor/cognitive dysfunction of the patient should be considered.

In choosing an access method, clinicians have to consider that the selected system balances accuracy of selection with speed, at the same time considering the cognitive load and learning requirements of patient's access method (Kent-Walsh et al., 2015).

The review of literature shows that the most important element of an access system is an adequate input device, which is considered to be a peripheral or a hardware performing the function of control signal production for the AAC device or a computer. Traditionally this type of devices include a keyboard, mouse and a touchscreen. Studying the field of assistive technologies, one can identify a wide range of modified or adapted keyboards, pointing devices and touchscreens, that are suitable for many pediatric patients. Moreover, more specialized technologies including switch interfaces and eye-gaze access technology create other possibilities for patients and clinicians.

An input device produces discrete input (key or switch press) or continuous input (pointing device controlled movement of a cursor). They can generate different number of signals. If the number of inputs increases, the level of accuracy required to control the input device increases simultaneously.

Selection of an input device depends on the type and range of motion that a patient can make, repeatedly and accurately. Patients who have just one reliable access point and use the movement of head, without sufficient accuracy, are a good candidate to apply a switch to access an AAC device. For pediatric patients requiring switches, there is a large number of options to use, encompassing mechanical switches of different activation pressures, electrical and proximity switches that don't require physical contact for activation. Part of the switches are designed for a particular access point, such as pneumatic switches controlled by air pressure changes in the oral cavity. Recent developments in switches that use electromyography provided the clinicians an opportunity for on body switching, that requires very little physical movement, and electrical activity in muscles can be converted into digital signals that could control the device (Virella et al., 2016). 
For the last decade, the development of eye-gaze access technology (technologies that allow patients to control an AAC device with movement or rest of gaze) has provided new options for some pediatric patients who previously had used indirect methods of selection. The application of eye-gaze technology can be not applicable for some children, and preliminary data shows that the time needed to acquire the technology efficiently may be much longer than other direct selection methods.

User feedback is one of the essential components for an access method to be effective. Mostly, a feedback system consists of a visual array of symbols or letters on a screen. A feedback system can include only auditory cues for patients with severe visual impairment, but comparative trials indicate that this method is much slower than visual cues.

It is well known that personal factors play an essential role in the adoption and application of AAC. Access methods can require differing cognitive loads, meaning that it is important for clinicians to take into consideration the developmental age of the individual patient. Access methods should be intuitive and minimize the amount of learning and time required to use them, allowing patients to have success in their use of the selected device. The patient's motivation to use the access is another key factor, as majority of access methods require practice and a long period of teaching. It is well known that the optimal functional outcome of AAC application is not the use of symbols, letters or devices, but direct participation through communication. This approach confirms that selection of an access method is an essential part of the successful implementation of any AAC system, and the application of an access method can't be a goal in itself. Clinical experience and accumulated data suggest that application of an access method should be always practiced when possible, focusing on functional goals and tasks (Pennington \& Mcconachie, 2001).

Current specifications of access show that the term must include not only the physical and technological issues of AAC system control, but also the cognitive and psycholinguistic abilities of the patient. Elaboration of the communication task, specifications of the environment, skills and the context of the communication partners are required points to be considered. 
A more proper definition of the term access is perceived as a non-speaking individuals participation in a communication including application of an AAC device, modifications in methods that the user controls the device, as well as any adjustments or restrictions present in the communication. An active communication partner who understands the utterances of an AAC user, and who is fully aware of the nature of message construction, can enhance access to the communication for the AAC user. Modifications and development of all aspects of communication and interaction should therefore be analyzed to support the best possible outcome for a pediatric patients using an AAC device.

Since access is considered as an integration of different interrelated factors, the selection of an appropriate functional method of access must be the result of applied multi-disciplinary assessment and intervention, conducted by Speech and Language Therapists, Psychologist, Occupational Therapists and Clinical Scientists or Assistive Technologists combining with the opinions and preferences of the patient/user and the family.

The path to inclusive education for children with rare neurological disorders

Education is the main area in developing a child's future. This concept is not well discussed in research publications on developmental disabilities. Not a single comprehensive publication on rare neurological disorders contain a special chapter or a developed concept on education. For decades before the inclusion concept was implemented, pediatric neurological patients with disabilities have traditionally been educated in special schools that have special rehabilitation services. For the last 3-4 decades, there has been a continuous process of inclusion in education system. This process aimed to integrate the children with disabilities into regular school education system. The integration/inclusion requires special assistance for these children. Inclusion process is accessible not for all children with neurological conditions, and encompasses mainly the children who are the most able. The system of inclusive education implies that relevant support for the disabled children is available in the school and necessary adaptations are made in teaching methods, materials, tests, requirements, and curriculum, so that all children can be integrated in teaching process regardless of degree of impairment. The roots of inclusive education are in social and human rights 
domains. Norway and Italy were pioneers in this field, and initiated generalized inclusion process in 1977. These countries closed almost all special schools.

According to the 2006 United Nations Convention on the Rights of People with Disabilities, countries should ensure inclusive education at all levels and lifelong learning directed to the full development of human potential and sense of dignity and self-worth. There is no evidence based data about the effectiveness of the transition process. Gillies and co-authors (Gillies et al., 2006) have conducted a populationbased retrospective study which involved a cohort of 3944 children with neurological conditions in New South Wales, Australia. The study analyzed the hospital data in correlation with educational outcome data (using the National Assessment Program 'Literacy and Numeracy'). This study showed that $67 \%$ of children with neurological conditions study in mainstream schools, and $30 \%$ of this cohort had test scores in the normal range. The highest proportion of children with regular scores were patients with hemiplegia and the lowest the children with tetraplegia or other rare neurological condition. Approximately $18 \%$ of this proportion needed special assistance. This logically reveals that the less impaired children were likely the ones reaching the minimum of standard scores. There was no information obtained about those who did not reach minimum level and part of this children was not necessarily illiterate. School participation is reflected not only in achievement test scores. An important indicator is participation in educational processes. Low achievement may result also from not proper testing procedures. Dynamic response to intervention tests provides a more adequate view on a child's potential for learning.

Children with rare neurological disorders encounter more participation barriers with increasing impairment severity. Successful participation also depends on the peculiarities typical for the course of the certain condition, as well as on the environmental characteristics including the school's inclusive culture, policies, and practice. The wide disparity of the proportion of children with rare neurological conditions in mainstream schools is mainly due to different volume of experience in teaching the children with special needs.

In the above mentioned study Gillies et al. showed that $33 \%$ of children with neurological conditions were in special schools, despite the fact that the Australian government had adopted the policy of inclusive 
education decades ago. There is still a long way to go to reach the ideal target model of inclusion for pediatric neurological patients.

More studies are needed to reveal how effectively inclusive education could be implemented, and will not overload teachers or children, preserving the quality of life for all categories of neurological patients and balancing between needs to learn skills and need to participate. In other words generating a synthesis between therapy and learning. If this strategy is feasible on a high-quality level for children with rare neurological conditions, who have severe, complex, or even multiple disabilities, it should work for patients with less severe symptomatology.

\section{Conclusions}

Enhancement of communication in patients with rare neurological disorders should be based on the integration of cognitive, psychological, or psycholinguistic models. For children with rare neurological disorders that eventually lead to speech, cognitive and psychological disturbances, AAC methods are the strategies of choice to facilitate communication. These tools with different access methods are used to support inclusion of children with rare neurological conditions into education system.

\section{References}

Lionti, T., Reid, S.M., White, S.M., \& Rowell, M.M.A. (2015). Population-based profile of 16 Australians with Prader-Willi syndrome trends in diagnosis, birth prevalence and birth characteristics. American journal of medical genetics. Part A. DOI: 10.1002/ajmg.a.36845

Antonell, A., del Campo, M., Magano, L.F., Kaufmann, L., Martinez de la Iglesia, J., Gallastegui, F., \& Perez-Jurado, L.A. (2010). Partial 7q11.23 deletions further implicate GTFI and GTF2IRD1 as the main genes responsible for the WilliamsBeuren syndrome neurocognitive profile. Journal of Medical Genetics, 47, 312 320. doi: 10.1136/jmg.2009.071712. Epub 2009 Nov 5. PMID: 19897463

Mervis, C.B., \& John, A.E. (2010). Cognitive and behavioral characteristics of children with Williams syndromeImplications for intervention approaches. American Journal of Medical Genetics Part C: Seminars in Medical Genetics, 154 C(2), 229-248. doi: 10.1002/ajmg.c.30263

Laureys, S., Pellas, F., van Eeckhout, P., Ghorbel, S., Schnakers, C., Perrin, F., Berr, J., Faymonville. M., Pantke, K.H., Damas, F., Lamy, M., Moonen, G., \& Goldman, S. (2005). The locked-in syndrome what is it like to be conscious but paralyzed and voiceless? Progress in brain research, 150, 495-511. DOI: 10.1016/S0079-6123(05)50034-7

Neul, J.L., Lane, J.B., Lee, H.S., Geerts, S., Barrish, J.O., Annese, F., \& Percy, A.K. (2014). Developmental delay in Rett syndrome. Data from the natural history 
Рідкісні неврологічні захворювання у дітей: сучасна парадигма...

study. Journal of Neurodevelopment Disorders, 6(1), 20. doi: 10.1186/18661955-6-20

Reichow, B., George-Puskar, A., Lutz, T., Smith, I.C., \& Volkmar, F.R. (2015). Brief report. Systematic review of Rett syndrome in males. Journal of Autism and Development Disorders, 45, 3377-3383. doi: 10.1007/s10803-015-2519-1

Borgestig, M., Sandqvist, J., Parsons, R., Falkmer, T., \& Hemmingsson, H. (2015). Eye gaze performance for children with severe physical impairmentsusing gazebased assistive technology - A longitudinal study. Assistive Technology, 28(2), 93-102. doi: 10.1080/10400435.2015.1092182

Carnahan, K.D., Arner, M., \& Gunnar, H.G. (2007). Association between gross motor function (GMFCS) and manual ability (MACS) in children with cerebral palsy. A population-based study of 359 children. BMC Musculoskelet Disord, 21(8), 50. https://doi.org/10.1186/1471-2474-8-50

Kent-Walsh, J., Murza, K.A., Malani, M.D., \& Binger, C. (2015). Effects of communication partner instruction on the communication of individuals using AACa meta-analysis. Augment Altern Commun, 31(4), 271-84. DOI:10.3109/07 434618.2015.1052153

Virella, D., Pennington, L., Andersen, G.L., et al. (2016). Classification systems of communication for use in epidemiological surveillance of children with cerebral palsy. Developmental Medicine \& Child Neurology, 58(3), 285-291. doi: 10.1111/ dmcn. 12866

Pennington, L., \& Mcconachie, H. (2001). Communication with children with severe motor impairments: the effects of speech intelligibility. International Journal of Language and Communication Disorders, 36(3), 371-394.

Gillies, R.M. (2006). Teachers' and students' verbal behaviours during cooperative and small-group learning. British Journal Educationfl Psychology, 76(2), 271-287. DOI:10.1348/000709905X52337

Schnewolf-Greulich, B., Stahlhut, M., Larsen, J.L., Syhler, B., \& Bisgaard, A.M. (2017). Functional abilities in aging women with Rett syndrome - the Danish cohort. Disabil Rehabil, 39(9), 911-918. doi: 10.3109/09638288.2016.1170896

Slavin, R.E. (1986). Best-evidence synthesis: An alternative to meta-analytic and traditional reviews. Educational Researcher, 15, 5-11.

\section{АНОТАЦІЯ}

Метою представленої роботи є виявлення оптимальної стратегії для покращення комунікації у пацієнтів з рідкісними неврологічними захворюваннями, використовуючи різні моделі втручання. Технології альтернативної комунікації швидко розвиваються, тому визначення методів для становлення комунікації й вибір альтернативної системи комунікації для дитини стає надзвичайно важливим. У дітей з рідкісними неврологічними захворюваннями часто спостерігаються комунікативні порушення. Для таких захворювань характерні моторні, когнітивні й сенсорні порушення. Мовна терапія, яка застосовується для пацієнтів цих категорій, представлена в різних наукових публікаціях. У процесі формуванні мовленнєвого повідомлення психотерапевт зазвичай використовує в комплексі різні механізми - когнітивні, психологічні, 
Rare Neurological Diseases in Children: Current Paradigm...

психолінгвістичні, щоб полегшити створення дітьми внутрішніх уявлень, які можуть бути закодовані й представлені в різних формах. Всебічна оцінка й використання відповідних систем додаткової та альтернативної комунікації (ДАК) $є$ важливими чинниками успіху втручань для осіб з рідкісними неврологічними захворюваннями, які мають складні комунікативні потреби. Оцінка комунікативних порущень, викликаних рідкісними неврологічними захворюваннями, $\epsilon$ важливим фрактором при створенні ДАК технологій для цих педіатричних пацієнтів. У представленому дослідженні використовувалися наступні методи: аналіз наукових досліджень, систематизація та узагальнення наукових даних. Встановлено, що відновлення комунікації у пацієнтів з рідкісними неврологічними захворюваннями повинно ґрунтуватися на інтеграції когнітивних, психологічних та психолінгвістичних моделей. Для дітей з рідкісними неврологічними захворюваннями, які в призводять до мовних, когнітивних і психологічних порушень, методи ДАК є стратегією вибору для полегшення комунікації. Ці інструменти з різними методами доступу можуть сприяти процесу інклюзії дітей з рідкісними неврологічними захворюваннями в системі освіти.

Ключові слова: альтернативні комунікаційні системи, інклюзивна освіта, рідкісні неврологічні захворювання.

\section{Авагян Арменуш, Мкртчян Хасмик, Петросян Тигран. Редкие неврологические заболевания у детей: современная парадигма коммуникационных вмешательств и инклюзии}

\section{АННОТАЦИЯ}

Целью представленной работы является выявление оптимальной стратегии для улучшения коммуникации у пациентов с редкими неврологическими заболеваниями, используя разные модели вмешательства. Технологии альтернативной коммуникации быстро развиваются, поэтому определение методов для развития коммуникации и выбор альтернативной системы коммуникации для ребенка становится чрезмерно важным. У детей с редкими неврологическими заболеваниями часто наблюдаются коммуникативные нарушения. Для таких заболеваний характерны моторные, когнитивные и сенсорные нарушения. Речевая терапия, которая применяется для пациентов этих категорий, представлена в различных научных публикациях. При формировании речевого сообщения психотерапевт обычно использует сочетание разных механизмов: когнитивных, психологических или психолингвистических, чтобы облегчить создание детьми внутренних представлений, которые могут быть закодированы и использованы в разных формах. Всесторонняя оценка и использование соответствующих 
систем дополнительной и альтернативной коммуникации (ДАК) являются необходимыми фокторами успеха вмешательств для лии с редкими неврологическими заболеваниями, которые имеют сложные коммуникативные потребности. Оценка коммуникативных нарушений, вызванных редкими неврологическими заболеваниями, является важным фактором при создании ДАК технологий для таких педиатрических пациентов. В представленном исследовании использовались следующие методы: анализ различных исследований, систематизация и обобщение научных данных. Восстановление коммуникации у пациентов с редкими неврологическими заболеваниями должно основываться на интеграции когнитивных, психологических или психолингвистических моделей. Для детей с редкими неврологическими заболеваниями, которые в конечном итоге приводят к речевым, когнитивным и психологическим нарушениям, методы ДАК являются стратегией выбора для облегчения коммуникации. Эти инструменты с различными методами доступа могут способствовать процессу инклюзии детей с редкими неврологическими заболеваниями в систему образования.

Ключевые слова: альтернативные коммуникационные системы, инклюзивное образование, редкие неврологические заболевания. 